\title{
How Does Macroeconomic Variables Affect Human Development Index
}

\author{
Nurjannah $^{1}$, Listriyanti Palangda ${ }^{2}$, Sri Purwaningsih Siswanto ${ }^{3}$, Ilham $\mathrm{Abu}^{4}$, \\ Sutrisno 5 \\ ${ }^{1}$ Department of Economic Education, Faculty of Economics, Universitas Negeri Makassar, Makassar, Indonesia \\ ${ }^{2}$ Department of Economic Education, Faculty of Economics, Universitas Negeri Manado, Minahasa, Indonesia \\ ${ }^{3}$ Department of Economic Education, Faculty of Economics, Universitas Negeri Manado, Minahasa, Indonesia \\ ${ }^{4}$ Department of Economic Education, Faculty of Teacher Training and Education, Universitas Mulawarman, \\ Samarinda, Indonesia \\ ${ }^{5}$ Department of Economic Education, Faculty of Teacher Training and Education, Universitas Mulawarman, \\ Samarinda, Indonesia \\ ${ }^{*}$ Corresponding author. Email: nurjannahfe@unm.ac.id
}

\begin{abstract}
This study aims to analyze the impact of government spending on the education and health sectors, economic growth and poverty levels on the Human Development Index (HDI) in South Sulawesi Province, Indonesia. This research is quantitative research. The type of data in the form of secondary data in the period 2009-2018. The data were processed using the OLS (Ordinary Least Square) model with multiple linear regression analysis. The results showed that government spending in the education and health sectors, economic growth and poverty levels had an effect on the Human Development Index (HDI) in South Sulawesi Province, Indonesia.
\end{abstract}

Keywords: Human Development Index, Government Expenditure, Economic Growth, Poverty.

\section{INTRODUCTION}

The development model currently being developed is a development in economic growth that is assessed through by human development. One of the benchmarks for measuring people's quality of life is the Human Development Index. HDI is a tool to assess differences in expectations, literacy, education and life measures of each country in the world. [1] in the results of his research stated that spending on education and health can lead to vulnerability to poverty.

HDI is measured through three indicators is the level of education, health and purchasing power. Achievement of human development is influenced by government activities that function in making regulations. Government spending is functioned in making government policies, including government priorities for the successful development of quality human resources from the fields of education and health. In the sector of government spending, it can be an appropriate way to encourage HDI if the expenditure more focuses on education, health, development, and agriculture [2].
Education and health are fundamental development goals. Health is welfare and education is mandatory in achieving a decent and valuable life, in this case either education or health, both of which are very important in shaping the broader human capabilities which are at the core of the meaning of development [3].

Economic growth is also related to human development. [4] Suggests that economic growth is the real output growth of an economy throughout the year as measured by the addition of Gross National Product or Gross Domestic Product. The achievement of a high level of economy is one of the main objectives of the basic implementation of macroeconomic.

In addition, poverty is also one of the factors that affect HDI. A significant reduction in the poverty line can promote human development and thereby increase the HDI in Indonesia in general and the province of South Sulawesi in particular. Poverty is very broad in scope and can affect various economic arrangements, such as in education, health, household spending, to food and beverages so that public obstacles or those experienced by the community can be overcome and 
evaluated. Based on this description, the researcher is interested in knowing and analyzing how the expansion of the human development index is increasing macroeconomic variables.

\section{LITERATURE REVIEW}

The economic model explains that there has been a measure of success in the economy through the economic growth approach to the human development approach. Human development is one of the indicators for the advancement of a country, which is said to be developed is not only calculated from its gross domestic income but also includes aspects of life expectancy as well as education and public health [5].

The Human Development Index is a composite that measures the average level of achievement of a country, there are 3 basic things for human development, namely length of life by measuring life expectancy since born, education by measuring and combining the number of literate and average adults and the average length of schooling, standard of living by measuring the expenditure of a predetermined average population. This underlies the amount set by the United Nations Development Program in the "Human Development Index Report 1990: Concept and Measurement of Human Development", which is the approach used as a measure of the level of human development [6].

Suggests that there are two costs of education, namely the cost of individual education and the cost of indirect education [7]. These individual direct educational costs are then directly related to the income per capita of the community. Today the demand for education is in line with the increasing need for formal education in the job market. This will directly affect the education budget, in the provision of educational facilities and infrastructure to the budget issued by the household itself. Meanwhile, the law in Indonesia regulates the health budget is Law No. 36 of 2009 which states that the central government's health budget is allocated a minimum of 5 percent of the APBN excluding salaries, while the provincial and district/city government health budgets are allocated a minimum of 10 percent of the APBD excluding salaries [8].

Economic growth is an increase in gross domestic income, regardless the rate of population growth, and changes in the structure of the economy. In classical economic theory, in the economic system, the free market will form an efficiency, where the economy is in full employment condition, and guarantees economic growth until a stationary state is reached. Meanwhile, Neo-classical theory serves as a basic tool for understanding the growth process in developed countries. Robert M. Solow is an economist who has developed neoclassical theory. In the Solow model assumption, namely that changes in physical capital factors (savings \& investment) and population growth or economic growth can be influenced by labor, while technology that reflects the level of efficiency is an exogenous variable and is considered as residual.

Poverty cannot be separated when related to HDI because an increase in HDI can reduce poverty, and vice versa. Likewise, government spending, especially in the fields of education and health, is a very important factor as a determinant of increasing human development [9]. In line with economic growth, it can work well if it is done well, and can be done by means, such as increasing the minimum wage, increasing the workforce and others [10]. The poverty line obtained from various previous studies always shows a negative relationship when it is associated with HDI, the state debt factor is also able to reduce poverty [11].

\section{RESEARCH METHOD}

This research is quantitative research. The data obtained is secondary data taken in the period 20092018 which is quantitative data. The independent variables in this study include government spending in the education sector, government spending in the health sector, economic growth and poverty levels. The dependent variable is the Human Development Index. The data that has been obtained is processed using statistical analysis, namely multiple linear regression analysis.

\section{RESULT AND DISCUSSION}

The results of research data processing are shown in Table 1.

Table 1. Statistical Test Results $t$

\begin{tabular}{|l|l|l|l|l|}
\hline \multicolumn{1}{|c|}{ Variable } & \multicolumn{1}{c|}{$\beta$} & \multicolumn{1}{c|}{ T } & Sig. & Results \\
\hline (Constant) & 86,630 & 39,385 & .000 & \\
\hline $\begin{array}{l}\text { Government } \\
\text { Expenditure } \\
\text { on } \\
\text { Education } \\
(\mathrm{X} 1)\end{array}$ & .070 & 2,334 & .067 & $\begin{array}{l}\text { Not } \\
\text { Significant }\end{array}$ \\
\hline $\begin{array}{l}\text { Health } \\
\text { Government } \\
\text { Expenditure } \\
\text { (X2) }\end{array}$ & .008 & .641 & .549 & $\begin{array}{l}\text { Not } \\
\text { Significant }\end{array}$ \\
\hline $\begin{array}{l}\text { Economic } \\
\text { Growth } \\
\text { (X3) }\end{array}$ & 2,542 & $-11,667$ & .000 & Significant \\
\hline $\begin{array}{l}\text { Poverty } \\
\text { (X4) }\end{array}$ & -.057 & $-2,330$ & .067 & $\begin{array}{l}\text { Not } \\
\text { Significant }\end{array}$ \\
\hline
\end{tabular}

Source: Results of research data processing, 2019.

The regression equation from the results of data processing contained in table 1 :

$$
Y=86.630+0.070 X_{1}+0.008 X_{2}+2.542 X_{3}-0.057 X_{4}+e
$$


From the regression coefficient value of the independent variable $\mathrm{X} 1$ it can be interpreted that every $1 \%$ increase in government spending in the education sector will cause an increase in HDI of $0.070 \%$. And from the regression coefficient value of the independent variable $\mathrm{X} 2$, it can be interpreted that every $1 \%$ increase in government spending in the health sector will cause an increase in HDI of $0.008 \%$. In the first and second hypotheses, the effect of government spending on education and health has a positive influence on human development [12], because indirectly education in a country can be a long-term investment capital, while in the health sector it is public expenditure which has its own place in the economy bylaws. As a means of supporting the fulfillment of government spending. This can be done by increasing the expenditure budget [13] or reducing spending in areas that are less important and urgent to fulfill [14].

Furthermore, from the regression coefficient value of the independent variable X3 it can be interpreted that every $1 \%$ increase in economic growth will cause an increase in HDI by $2.542 \%$. The third hypothesis based on the results of processed data is in line with several studies such as research (15) which states that economic growth has a significant positive effect if it is associated with human development. Economic growth is one of the most important factors to continue to be improved, because the better economic growth will be able to improve a country in the economy [16].

Meanwhile, from the regression coefficient value of the independent variable $\mathrm{X} 4$ it can be interpreted that every $1 \%$ decrease in the poverty rate will cause an increase in HDI of $0.057 \%$. In the fourth hypothesis that poverty reduction can increase human development, this is in line with Pasquale's research [17]. However, the level of poverty reduction can be determined by the direct involvement of the poor in an economic activity which can also increase economic growth [18]. Poverty reduction on its impact on human development is negative [19]. One of the main problems that could threaten if it continues to increase is the increase in violence against the poor [20] so that it needs to be overcome, one of which is by increasing the education and health sectors [21]. By improving the pattern of household expenditure of the poor, it can improve the scale of poverty in the community and can be used as evaluation material. The government in this case can also impose an increase in the minimum wage for workers in order to increase income to fulfill their daily needs.

\section{CONCLUSION}

The results showed that government spending in both the education and health sectors has a positive effect on the HDI, especially economic growth which has a positive and significant effect on the HDI. Meanwhile, the poverty rate has a negative effect on the HDI in Indonesia and specifically in the province of South Sulawesi.

It can be seen from this research that increasing human development can be achieved through reducing the poverty line and increasing spending on the education and health sectors, as well as continuously increasing economic growth. Therefore, the increasing human development index can also affect poverty, economic growth, and national income.

The government, in this case the central party in a country, is expected to be able to take good policies to support. As in budget expenditures, it must be accompanied by transparency to avoid criminal acts in this case corruption in order to optimize the budget issued.

\section{ACKNOWLEDGMENTS}

We thank the anonymous reviewers who have provided constructive suggestions for improving this article.

\section{REFERENCE}

[1] Aigheyisi, Oziengbe Scott. (2013). Economic Growth and Human Development Effect of Globalization in Nigeria: Evidence in the Democratic Era.

[2] Amaluddin., Rukmuin W. Payapo., Abdul A. Laitupa, Mohammad R. Serang. (2018). A Modified Human Development Index and Poverty in the Villages of West Seram Regency, Maluku Province, Indonesia.

[3] D.I. Eyarefe., P. Sanusi. (2015). Comparative Analysis of Government Funding on Education and Economic Growth During The Civilian And Military Regimes: Lessons From Nigeria.

[4] Fayissa, B. and Nsiah, C. (2010). The impact of remittances on economic growth and development in Africa.

[5] Ferdinand Niyimbanira. (2017). International Journal of Economics and Financial Issues Analysis of the Impact of Economic Growth on Income Inequality and Poverty in South Africa: The Case of Mpumalanga Province.

[6] God's time Osekhebhen Eigbiremolen., Uchechi Shirley Anaduaka. (2014). Human Capital Development and Economic Growth: The Nigeria Experience.

[7] Irham Iskandar. (2017). Effect of Human Development Index Fund on Economic Growth Through a Special Autonomy. 
[8] Jong In Kim., Gukbin Kim. (2014). Factors affecting the survival probability ofbecoming a centenarian for those aged 70 , based on the human mortality database: income, health expenditure, telephone, and sanitation.

[9] Julian May., Kathleen Diga. (2015). Progress Towards Resolving the Measurement Link Between ICT and Poverty Reduction.

[10] Kazi Abdur Rouf. (2015). While Poverty is a Global Problem Resulting from Global Issues, its Definition and Solution can only be Found Locally.

[11] M. Santric-Milicevic., V. Vasic., Z. Terzic-Supic. (2016). Do health care workforce, population, and service provision significantly contribute to the total health expenditure? An econometric analysis of Serbia.

[12] Madhusudan Ghosh. (2006). Economic Growth and Human Development in Indian States.

[13] Maryam Asghari. (2016). The Role of Corruption and Healthcare Expenditure in the Persian Gulf Region's Health System.

[14] Michael Appiah., Richard Amoasi., Doreen Idan Frowne. (2019). Human Development and Its Effects on Economic Growth and Development.

[15] Nathapornpan Piyaareekul Uttama. (2015). Foreign Direct Investment and the Poverty Reduction Nexus in Southeast Asia.

[16] Oluwatobi, Stephen. O, Ogunrinola, I. Oluranti. (2011). Government Expenditure on Human Capital Development: Implications for Economic Growth in Nigeria.

[17] Pasquale Tridico. (2010). Growth, Inequality and Poverty in Emerging and Transition Economies.

[18] Pavitra Paul. (2018). The distributive fairness of out-of-pocket healthcare expenditure in the Russian Federation.

[19] Suman Seth., Antonio Villar. (2017). Human Development, Inequality, and Poverty: Empirical Findings.

[20] Suwandi. (2016). The Influence of Economic Growth on Poverty, Investment, and Human Development Index in Fak, Fak District, West Papua Indonesia.

[21] Wahyu, T., R. 2014. Identification of Macroeconomic Variables in Central Java Province. Journal of Applied Quantitative Economics, 7(2): 155-167 